\title{
The Effect of Conflict of Interest on Biomedical Research and Clinical Practice Guidelines: Can We Trust the Evidence in Evidence-Based Medicine?
}

\author{
John Abramson, MD, MSFP, and Barbara Starfield, MD, MPH
}

Funding for clinical research has changed dramatically over the past 2 or 3 decades. Before 1970, few clinical studies were sponsored solely by the drug companies. ${ }^{1}$ A 1982 article in the journal Science noted the transition: "Scientists who 10 years ago would have snubbed their academic noses at industrial money now eagerly seek it out." ${ }^{2}$ When President Reagan came to Washington, inheriting a sluggish economy and espousing small government, federal support of medical research declined even more rapidly. ${ }^{3}$

Universities had little choice but to turn to commercial sources of funding. ${ }^{4}$ Between 1977 and 1990, drug company expenditures on research and development increased 6-fold, much of which went to support university-based clinical research. ${ }^{5}$

According to a report recently issued by the British House of Commons, "Approximately 75\% of clinical trials published in The Lancet, the New England Fournal of Medicine (NEFM), and the Fournal of the American Medical Association ( $7 A M A)$ are industry funded." ${ }^{\circ}$ But only approximately a third of this commercially sponsored research is now being done in universities and academic medical centers, the remainder is being conducted by forprofit research companies. ${ }^{7}$ From the drug companies' point of view, this makes perfect sense-their studies can be done quicker, cheaper, and with less red tape. The removal of research from academic centers also gives pharmaceutical companies greater control over the design of studies, analysis of data, and publication of results. ${ }^{8}$

Submitted, revised 11 July 2005.

From Ambulatory Care and Prevention, Harvard Medical School, Cambridge, MA (JA); and Johns Hopkins University and Medical Institutions, Baltimore, MD (BS)

Conflict of interest: JA is serving as the plaintiffs' expert on cases involving the drug industry.

Corresponding author: John Abramson, MD, MSFP (e-mail: john_abramson@hms.harvard.edu).
The end result: among even the highest quality clinical research (included in Cochrane reviews) the odds are 5.3 times greater that commercially funded studies will support their sponsors' products than noncommercially funded studies. The authors conclude, "Readers should carefully evaluate whether conclusions in randomized trials are supported by data." Careful readers with enough time can sometimes spot discrepancies between data and conclusions in published studies. However, the drug companies typically retain control over the data from their sponsored trials so the majority of the researchers don't have open access to the results from their own studies. ${ }^{8,10}$ The editors, peer reviewers, and editorial writers who are trusted to evaluate the accuracy of the analyses are thus often not able to do so.

As these funding changes unfolded (along with the drug companies' direct funding of an evergreater share of the budget of the Center for Drug Evaluation and Research, the division of the US Food and Drug Administration [FDA] that approves new drugs and oversees drug safety), ${ }^{11}$ we have seen an accelerating series of prescription drug debacles. For instance, there was the withdrawal of the diabetes drug troglitazone (Rezulin) in the United States-suspected as the cause of almost 400 deaths ${ }^{12}$-more than 2 years after it was removed from the British market, ${ }^{2}$ and the about face on routine hormone replacement therapy after "experts" had made this a mainstay of routine medical care for postmenopausal women. ${ }^{13}$

No class of drugs has suffered so great a reversal of fortune as the COX-2 inhibitors. Most of the pieces of this unfolding saga are now available, providing an informative case study about the extent to which commercial interests can and do distort the scientific evidence that guides our medical decisions. The actual data from VIGOR, Merck's large study of rofecoxib (Vioxx), and CLASS, 
Pharmacia's (now Pfizer's) large study of celecoxib (Celebrex), have been available on the FDA website since its Advisory Committee meetings of February, 2001. ${ }^{14,15}$

Neither drug provides any better relief of arthritis symptoms or pain than much less expensive over the counter nonsteroidal anti-inflammatory drugs (NSAIDs). ${ }^{16,17}$ In the VIGOR study, the people who took $50 \mathrm{mg}$ of Vioxx per day developed significantly more serious cardiovascular complications (heart attacks, strokes, and blood clots), whether or not they had a previous history of cardiovascular disease. In fact, the highly touted gastrointestinal (GI) benefit of Vioxx was actually overshadowed by the increase in cardiovascular harm to patients in this study. Most important, those who took Vioxx developed significantly more serious complications overall $(21 \%)$ than those treated with $1000 \mathrm{mg}$ of naproxen per day. In absolute numbers, treating 100 patients in the VIGOR study for 1 year with Vioxx instead of naproxen led to $2 \frac{1}{2}$ times more serious complications - the kind that cause hospitalization, permanent disability, cancer, or death. ${ }^{18}$

The results of the CLASS study showed that Celebrex causes no fewer serious GI complications than older NSAIDs. ${ }^{19}$ Overall, the people who took Celebrex developed $11 \%$ more serious complications than those taking the older drugs (not statistically significant, but certainly not evidence of a safety advantage for the newer and much more expensive drug).

You might well conclude that the manufacturersponsored CLASS and VIGOR studies are evidence of the integrity of commercially sponsored research, and clearly they are. But why did American doctors then prescribe $\$ 20$ billion worth of Celebrex and Vioxx after the FDA and the manufacturers knew that they were no safer (Vioxx significantly more dangerous), no more effective, and cost 7 to 20 times more than generic alternatives? The answer lies in the process by which raw data becomes medical "knowledge"-through publication in respected medical journals and incorporation into clinical practice guidelines.

The $7 A M A$ published the results of the CLASS study in September of $2000 .^{20}$ The article concluded that Celebrex "when used for 6 months ... is associated with a lower incidence" of GI complications. But CLASS was a 12 -month study, and all 12 months had been completed at the time the manuscript reporting the results of only the first half of the study was submitted to $7 A M A$. In the unreported second 6 months of the study, all but one of the 7 serious GI complications occurred in people taking Celebrex, not older NSAIDs. All 16 of the authors of this article had financial ties to or were employed by the manufacturer of Celebrex.

When the editor of $7 A M A$ learned that data from only the first half of the study had been included in the article, she told the Washington Post, "I am disheartened to hear that they had those data at the time that they submitted [the manuscript] to us... We are functioning on a level of trust that was, perhaps, broken." ${ }^{21}$ Reprints of this article distributed by drug reps for marketing purposes were stamped with a disclaimer stating that it contains "Comparative results that are not supported by substantial clinical evidence" (presumedly based on the FDA's rejection of the manufacturer's analysis of the data from only the first half of the study). Nonetheless, the article was never retracted by the journal.

The NEFM published the results of the VIGOR study in November of $2000 .{ }^{22}$ This article concluded that Vioxx causes fewer serious GI complications than naproxen and left even diligent readers with the impression that for most patients, Vioxx is safer than naproxen. Although the NEFM article reported that patients taking Vioxx who had a previous history of cardiovascular disease were at greater risk of suffering a myocardial infarction, it failed to report that patients who took Vioxx developed significantly more serious thrombotic cardiovascular complications in toto (the prespecified cardiovascular outcome, not myocardial infarction alone) whether or not they had a previous history of cardiovascular problems. The article also failed to report that patients who took Vioxx developed overall significantly more serious illnesses than those who took naproxen. All 13 of the authors of this article had financial ties to or were employed by Merck. (The NEFM article did report that those who took Vioxx were more likely to suffer myocardial infarction but that this risk was not statistically significant in those without a previous history of cardiovascular disease.)

In August 2001, the NEFM published a "Drug Therapy" review article about Vioxx and Cele$\operatorname{brex}^{23}$ that further contributed to doctors' misperceptions of these drugs. The review acknowledged the increased risk of cardiovascular complications 
associated with Vioxx, but then made the statement that this statistically significant finding "may reflect the play of chance" because the total number of events was small, fewer than 70. (The review didn't apply the same reasoning to the highly touted reduction of serious GI problems, even though the total number of events was only 53.) Belying this "play of chance" theory, the FDA's statistical reviewer had concluded 7 months earlier that the odds that the increased risk of major cardiovascular complications were because of the play of chance alone were quite small: between 1 in 625 and 1 in $10,000 .^{18}$

The NEFM drug therapy article was kind to Celebrex as well. Despite FDA analysts having reported 7 months earlier that Celebrex is no less likely than older NSAIDs to cause serious GI complications, the review article concluded that treatment with COX-2 inhibitors (ie, Vioxx and Celebrex) "causes significantly fewer serious gastrointestinal adverse events than does treatment with nonselective NSAIDs." Both of the authors of this article had financial ties to the manufacturers of both Vioxx and Celebrex.

The American College of Rheumatology issued clinical guidelines for the treatment of osteoarthritis of the hip and knee in 2000. ${ }^{24}$ Immediately following acetaminophen in the recommended list of "pharmacologic therapy for patients with osteoarthritis" were COX-2 specific inhibitors. Notwithstanding the results of the VIGOR study showing that Vioxx is significantly more dangerous than older alternatives and the CLASS study showing that Celebrex is no gentler on the stomach than older NSAIDs, these guidelines remained on the government's guideline website ${ }^{25}$ until approximately the time that Vioxx was withdrawn from the market. All 4 of the authors of these guidelines had financial ties to the manufacturers of Celebrex and/or Vioxx.

Financial ties between the experts who formulate guidelines and drug companies whose drugs are being considered are not unusual. A study published in $7 A M A$ shows that $59 \%$ of the experts participating in guideline creation have such financial ties. ${ }^{26}$ There were no such conflicts of interest disclosed in the July 2004 update of the National Cholesterol Education Program's (NCEP) recommendations for lowering cholesterol with statins published in Circulation. ${ }^{27}$ Just 1 week after the recommendations were published as conflicts started to appear in the press, the National Institutes of Health (NIH) put the complete list on its website: 8 of the 9 authors had financial ties to statin makers. ${ }^{28}$ In December of 2004, Pulitzer Prize winning journalist, David Willman reported in the Los Angeles Times that one of the authors of the NCEP update, a full-time employee of the National Heart, Lung, and Blood Institute (NHLBI) overseeing the formulation of the cholesterol guidelines, received $\$ 114,000$ in consulting fees from statin makers between 2001 and 2003 in addition to his full-time salary. ${ }^{29}$ Willman's article contributed to NIH's adoption of a policy that precludes conflicts of interest among its scientists, but it did not lead to a re-evaluation of the NCEP recommendations.

So what are dedicated clinicians to do? The first step is to give up the illusion that the primary purpose of modern medical research is to improve Americans' health most effectively and efficiently. In our opinion, the primary purpose of commercially funded clinical research is to maximize financial return on investment, not health.

Although one can make a case that the purpose of an industry is to make a profit and not necessarily to serve the public good, it is difficult to accept this as a justification for the behavior of medical scientists and regulatory agencies. With more than half of the budget for the Center for Drug Evaluation and Research now paid directly by the drug companies, ${ }^{11}$ the FDA itself has a conflict in ensuring the safety and effectiveness of the drugs that are prescribed for Americans. Medical journals are ill equipped to withstand the drug companies' financial pressure, research and statistical capacity, commercial ties with most recognized experts, and lack of transparency in the research they fund. Universities have become dependent on drug money and are also engaging in their own entrepreneurial activities. Most specialty medical societies and large nonprofit health advocacy organizations like the American Heart Association, ${ }^{30}$ the Arthritis Foundation, ${ }^{31}$ and the American Diabetes Association ${ }^{32}$ receive a large part of their funding from the drug companies. And approximately $70 \%$ of physicians' continuing medical education is now paid for by the drug and other medical industries. ${ }^{33}$

As commercial interests play an ever larger role in directing our medical practice toward the latest tests, drugs, and procedures, the ideals of family medicine-combining the art and science of med- 
icine in the primary care of patients and families over time-are increasingly challenged. The disparities in salary, the burdens of managed care, the breadth of our medical responsibility, and the difficulty in demarcating professional and personal time are growing. As a result, the number of graduates of American medical schools choosing careers in family medicine has declined by more than half in the past 8 years. ${ }^{34}$

In this highly commercialized environment, how do we sustain the ideals that brought us to family medicine? We now know enough about the limitations of "evidence" to be much more cautious about what passes for it. ${ }^{35-37}$ Perhaps the family medicine journals, individually or in concert, could start sections of their journals for the specific purpose of critically reviewing the results of published trials.

Finally, we family physicians have a professional responsibility to be less naive about the inherent divergence of our patients' and the drug companies' best interests. Our patients must come first.

\section{References}

1. Andreoli TE. The undermining of academic medicine. Academe 1999;6:32-37. Available from: http://www.aaup.org/publications/Academe/1999/ 99nd/ND99Andr.htm, accessed 06/14/05.

2. Krimsky S. Science in the private interest. Lanham (MD): Rowman and Littlefield; 2003.

3. Culliton BJ. The academic-industrial complex. Science 1982;216:960-2.

4. Bok D. Universities in the marketplace. Princeton (NJ): Princeton University Press; 2003.

5. Dramatic growth of research and development (http:// www.phrma.org/publications/publications/profile02/ 2003\%20CHAPTER\%202.pdf accessed 6/14/05). In: Pharmaceutical Research and Manufacturers of America, editor. Pharmaceutical Industry Profile 2003. Washington (DC): Pharmaceutical Research and Manufacturers of America; 2003.

6. The House of Commons Health Committee, The Influence of the Pharmaceutical Industry, Volume 1. April 5, 2005, p. 55. Available from: http://www. parliament.the-stationery-office.co.uk/pa/cm200405/ cmselect/cmhealth/42/42.pdf, accessed 6/08/05.

7. Petersen M. Madison Ave. has growing role in the business of drug research. New York Times, November 22, 2002.

8. Bodenheimer T. Uneasy alliance-clinical investigators and the pharmaceutical industry. N Engl J Med 2000;342:1539-44.

9. Als-Nielsen B, Chen W, Gluud C, Kjaergard LL. Association of funding and conclusions in random- ized drug trials: a reflection of treatment effect or adverse events? JAMA 2003;290:921-8.

10. Schulman KA, Seils DM, Timbie JW, et al. A national survey of provisions in clinical-trial agreements between medical schools and industry sponsors. N Engl J Med 2002;347:1335-41.

11. Effect of user fees on drug approval times, withdrawals, and other agency activities. United States General Accounting Office, September, 2002, p. 9. Available from: http://www.gao.gov/new.items/d02958.pdf, accessed 6/27/05.

12. Willman D. Risk was known as FDA OKd fatal drug. Los Angeles Times. March 11, 2001.

13. American College of Physicians. Guidelines for Counseling Postmenopausal Women About Preventive Hormone Therapy. Ann Intern Med 1992;117: $1038-41$.

14. FDA Arthritis Advisory Committee Briefing Information, February 8, 2001. Available from: http:// www.fda.gov/ohrms/dockets/ac/01/briefing/3677b1. htm, accessed 6/27/05.

15. FDA Arthritis Advisory Committee Briefing Information, February 7, 2001. Available from: http:// www.fda.gov/ohrms/dockets/ac/01/briefing/3677b1. htm, accessed 6/27/05.

16. Witter J. FDA Advisory Committee Briefing Document, Celebrex capsules, Medical Officer Review, February 7, 2001. Available from: http://www.fda. gov/ohrms/dockets/ac/01/briefing/3677b1_03_med. doc, accessed 6/28/05.

17. Villalba ML. FDA Advisory Committee Briefing Document, Vioxx gastrointestinal safety, February 8, 2001. Available from: http://www.fda.gov/ohrms/ dockets/ac/01/briefing/3677b2_03_med.pdf, accessed 9/16/2001.

18. Li Q. FDA Advisory Committee Briefing Document, Statistical Review, February 8, 2001. Available from: http://www.fda.gov/ohrms/dockets/ac/ 01/briefing/3677b2_04_stats.doc, accessed 6/27/05.

19. FDA Medical Officer's Gastroenterology Advisory Committee Briefing Document, February 7, 2001. Available from: http://www.fda.gov/ohrms/dockets/ ac/01/briefing/3677b1_05_gi.doc, accessed 6/28/05.

20. Silverstein FE, Faich G, Goldstein JL, et al. Gastrointestinal toxicity with celecoxib vs nonsteroidal antiinflammatory drugs for osteoarthritis and rheumatoid arthritis: The CLASS study: a randomized controlled trial. JAMA 2000;284:1247-55.

21. Okie S. Missing data on Celebrex full study altered picture of drug. Washington Post, August 5, 2001; A11.

22. Bombardier C, Laine L, Reicin A, Shapiro D, Burgos-Vargas R, et al. Comparison of upper gastrointestinal toxicity of rofecoxib and naproxen in patients with rheumatoid arthritis. The VIGOR study group. N Engl J Med 2000;343:1520-8.

23. FitzGerald GA, Patrono C. The coxibs, selective 
inhibitors of cyclooxygenase-2. N Engl J Med 2001; 345:433-42.

24. American College of Rheumatology Subcommittee on Osteoarthritis Guidelines. Recommendations for the medical management of osteoarthritis of the hip and knee: 2000 update. Arthritis Rheum 2000;43: 1905-15.

25. National Guideline Clearinghouse. Available from: http://www.guidelines.gov/

26. Choudhry NK, Stelfox HT, Detsky AS. Relationships between authors of clinical practice guidelines and the pharmaceutical industry. JAMA 2002;287: 612-7.

27. Grundy SM, Cleeman JI, Merz CN, et al. Implications of recent clinical trials for the National Cholesterol Education Program Adult Treatment Panel III guidelines. Circulation 2004;110:227-39.

28. National Cholesterol Education Program. Third Report of the Expert Panel on Detection, Evaluation, and Treatment of High Blood Cholesterol in Adults (Adult Treatment Panel III). Available from: http://www.nhlbi.nih.gov/guidelines/cholesterol/ atp3upd04_disclose.htm accessed 6/14/05. Bethesda (MD): National Heart, Lung, and Blood Institute, 2004.

29. Willman D. The National Institutes of Health: public servant or private marketer? Los Angeles Times, December 22, 2004;1.

30. American Heart Association. American Heart Association Annual Report 2004: Learn and Live.
Available from: http://www.americanheart.org/ downloadable/heart/1106163695297FINAL\% 20Annual04\%20ASA\%20Update.pdf, accessed 6/14/ 05. Dallas (TX): American Heart Association, 2004.

31. Arthritis Foundation, Arthritis Foundation Annual Report 2002: Think it's just arthritis? The truth hurts. Available from: http://www.arthritis.org/resources/ aboutus/Annual_Reports/2002/Annual\%20Report. Final.pdf, accessed 6-14-05). Atlanta (GA): Arthritis Foundation, 2002.

32. American Diabetes Association. American Diabetes Association Report 2004: rising to meet the challenge. Available from: http://www.diabetes.org/ uedocuments/AnnualFINAL.pdf, accessed 6-14-05. Alexandria (VA): American Diabetes Association, 2005.

33. Relman AS. Industry sponsorship of continuing medical education-reply. JAMA 2003;290:1150.

34. 2005 Match Information Sheet, American Academy of Family Practice. Available from: http://www.aafp. org/match/graph05.html, accessed 6/27/05.

35. Kravitz RL, Duan N, Braslow J. Evidence-based medicine, heterogeneity of treatment effects, and the trouble with averages. Milbank Q 2004;82:661-87.

36. Rothwell PM. External validity of randomised controlled trials: to whom do the results of this trial apply? Lancet 2005;365:82-93.

37. Steinberg EP, Luce BR. Evidence based? Caveat emptor! Health Aff 2005;24:80-92. 